\title{
Distribution of Aedes albopictus (Diptera, Culicidae) in southwestern Pacific countries, with a first report from the Kingdom of Tonga
}

\author{
Laurent Guillaumot ${ }^{*}$, Reynold Ofanoa ${ }^{2}$, Lucien Swillen ${ }^{3}$, Narendra Singh ${ }^{4}$, Hervé C Bossin ${ }^{5}$ and Francis Schaffner ${ }^{6}$
}

\begin{abstract}
Background: Aedes (Stegomyia) albopictus is currently one of the most notorious globally invasive mosquito species. Its medical importance is well documented, and its fast expansion throughout most continents is being monitored with concern. It is generally assumed that its expansion through the Western Pacific island countries has not progressed since its establishment in Fiji in 1989. However, the current status of Ae. albopictus in the Pacific region is largely unknown.

Findings: According to data from the literature and our own observations, Ae. albopictus is currently present in the following countries of the southern Pacific region: Papua New Guinea, Solomon Islands, Fiji, and the Kingdom of Tonga, where it was first detected in July 2011. It is absent from New Caledonia and French Polynesia where routine entomological surveillance is carried out, and was not detected during entomological work in 2007, either on the Cook Islands or on the Wallis and Futuna Islands. The species was not reported from American Samoa in 2004, but it is mentioned as probably present in Vanuatu. This is the first report of Ae. albopictus in Tonga.

Conclusions: The introduction and establishment of Ae. albopictus in Tonga was expected due to the geographical proximity of this country to Fiji where the species is strongly established. The pathway of introduction is unknown. The expansion of Ae. albopictus in the Pacific region poses an increasing threat to public health given the role this mosquito plays as primary vector of emerging infectious diseases such as Chikungunya fever.
\end{abstract}

Keywords: Aedes albopictus, Vector, Distribution, Pacific islands, Tonga, Introduction

\section{Background}

The "Asian tiger mosquito" Aedes (Stegomyia) albopictus (Skuse, 1895) is nowadays the most notorious invasive Culicidae. From its native range in Asia, the species has spread throughout the Americas, Europe and Africa, mainly via international trade in used tires [1]. Its capacity to transmit a large number of arboviruses is well documented. Although less efficient than Aedes aegypti for the dengue viruses transmission, it was responsible for large dengue epidemics in Japan in 1942-1945 [2], for the DEN-1 outbreak in Hawaii in 2001 [3] and for the DEN-2 outbreaks in La Reunion in 1977-78 and 2004 [4,5]. Being the sole vector of the severe

\footnotetext{
* Correspondence: Iguillaumot@pasteur.nc

'Institut Pasteur de Nouvelle Calédonie, 9-11 Avenue Paul Doumer, Association Pasteur International Network ,Nouvelle-caledonie, Noumea BP 61, 98845, New Caledonia

Full list of author information is available at the end of the article
}

chikungunya epidemic in La Reunion and other islands of the Indian Ocean in 2005-06 [6], Ae. albopictus was also responsible for a chikungunya outbreak in Italy in 2007 [7] as well as for local chikungunya and dengue transmissions in Southern France in 2010 [8]. Aedes albopictus is suspected to play a prominent role in outbreaks of these two diseases in Central Africa [9] and in addition, it is a potential vector of many other arboviruses, including yellow fever, as can be deduced from laboratory experiments $[10,11]$. Although the species efficiently transmits the dog heartworm Dirofilaria immitis [12], it is a poor vector of human filariasis [13].

The distribution of Ae. albopictus across the Pacific Island Countries and Territories (PICTs) is patchy. Several islands of the Northern hemisphere like Taiwan and the Japanese islands are part of its native area. However, it is not present on other Northern Pacific islands like Yap in the Federated States of Micronesia, despite continuous 
traffic of passengers and goods including tires from the neighboring Guam where Ae. albopictus is abundant. In Yap, the local Stegomyia species Aedes hensilli seems to prevent its establishment [14], possibly echoing John Belkin's 1962 statement: “Aedes albopictus does not occur in the South Pacific. It is unlikely that it will become established, for it does not seem to be able to compete with other members of the scutellaris group" [15]. Indeed, an intentional introduction of Ae. albopictus on a Tuamotu atoll in an attempt to displace the local filariasis vector Aedes polynesiensis failed [13]. Eventually, Ae. albopictus was reported in Papua New Guinea in 1970[16], in The Solomon Islands in 1979 [17], but only in 1989 in another South Pacific country, namely Fiji [18]. No other introduction has been reported in any other South Pacific island country since then.

A list published in 1995 [19] to which various authors are referring mentions its presence in 11 countries/territories of this region. We assume this is/ was not substantiated since (1) the sources are not mentioned, (2) except for the countries previously mentioned, we were unable to find any ancient or recent corroborating data in the literature, and (3) most of the reports do not match our observations.

Here, we describe and discuss the situation with regard to Ae. albopictus in all PICTs of the southern hemisphere, and we report the first finding of the species in the Kingdom of Tonga (Figure 1).

\section{Findings}

The overall situation in the PICTs is summarized in Table 1 and more details are given below, except for countries where Ae. albopictus is known to have been established for a long time (Fiji, Papua New Guinea, Solomon Islands).

In New Caledonia, the species is currently absent. Routine mosquito surveillance, aiming at monitoring dengue and chikungunya vector populations and detecting invasive species around ports of entry (harbor and airport), is carried out using regular larval and adult collections (sticky ovitraps, [20], BG Sentinel ${ }^{\circledR}$ traps,

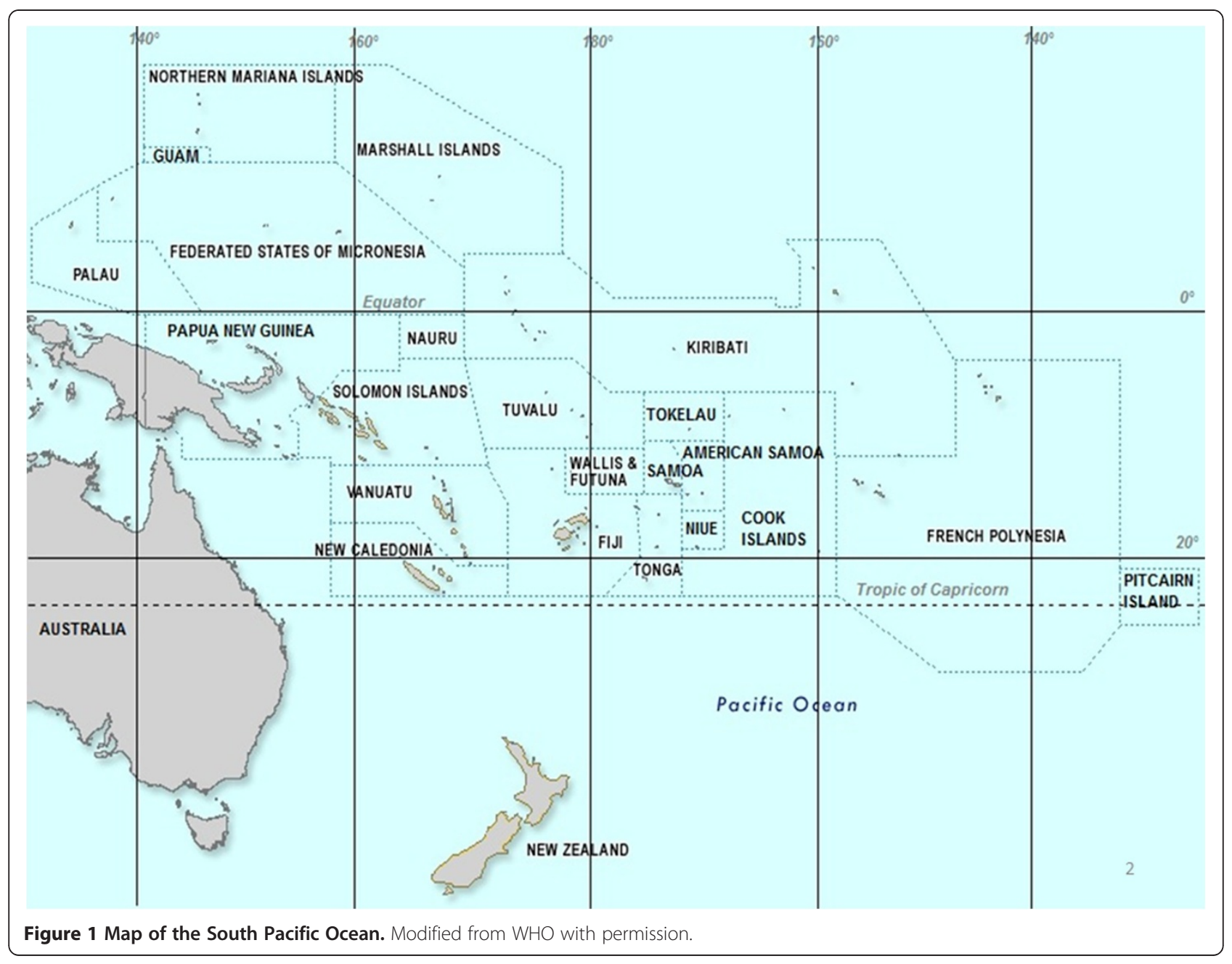


Table 1 Status of Aedes albopictus in the 17 South Pacific island countries and territories

\begin{tabular}{|c|c|c|}
\hline $\begin{array}{l}\text { Countries and } \\
\text { Territories }\end{array}$ & $\begin{array}{l}\text { Status of Aedes } \\
\text { albopictus }\end{array}$ & References \\
\hline Cook Islands & $\begin{array}{c}\text { Absent } \\
\text { (data from 2007) }\end{array}$ & IPNC reports \\
\hline Fiji & Present & Laille et al. 1990 \\
\hline $\begin{array}{l}\text { French Polynesia } \\
\text { (Tahiti) }\end{array}$ & Absent & ILM data \\
\hline Kiribati & Unknown & - \\
\hline Nauru & Unknown & - \\
\hline New Caledonia & Absent & IPNC reports \\
\hline Nive & Unknown & - \\
\hline Papua New Guinea & Present & Cooper et al. 1994 \\
\hline Pitcairn & Unknown & - \\
\hline American Samoa & $\begin{array}{c}\text { Absent } \\
\text { (data from 2004) }\end{array}$ & Lambdin et al. 2009 \\
\hline Western Samoa & Unkown & - \\
\hline Solomon Islands & Present & Elliott, 1980 \\
\hline Tokelau & Unknown & - \\
\hline Tonga & Present & This study \\
\hline Tuvalu & Unknown & - \\
\hline Vanuatu & Presence suspected & Chang Moh Seng, pers. co \\
\hline Wallis and Futuna & Absent (data from 2007) & IPNC reports \\
\hline
\end{tabular}

Countries and territories where Ae. albopictus is present are in bold.

Biogents, Germany) in urban and rural areas. Overall, up to 23,000 mosquitoes are identified annually. Aedes albopictus has never been recorded, either on the mainland or on the Loyalty Islands (Institut Pasteur of New Caledonia - IPNC annual reports, unpublished).

In French Polynesia, the species is currently absent. Mosquito sampling is frequently conducted for research or surveillance purposes on several archipelagoes (Society Islands, Tuamotu and Marquesas). Sampling is mostly done using ovitraps and BG Sentinel ${ }^{\circledR}$ traps. Aedes albopictus has not been detected so far.

On Wallis and Futuna Islands, entomological investigations were carried out by IPNC during a dengue outbreak in 2002 and 2003, and entomological records were updated and extended to the Horne group (Futuna and Alofi islands) in August 2007, supporting that Ae. albopictus was absent. A total of 3,918 mosquitoes, collected at all stages and in all types of environments including larval sampling in tires and other artificial and natural containers, were identified during these surveys. The prevalent mosquito species was Ae. polynesiensis, and a small population of Ae. aegypti was found in the main village. No Ae. albopictus specimens were found, either on Wallis island or on the Futuna and Alofi islands (IPNC reports, unpublished). However, no field data are available for the last 5 years.
On Cook Islands, the species was absent in 2007 during the last field investigation on the main island Rarotonga. A training workshop for vector surveillance and control was conducted there in collaboration with the Secretariat of the Pacific Community in September 2007. This entomological training included adult mosquito field trapping (CDC light trap and BG Sentinel ${ }^{\circledR}$ traps) and immature collection targeting container breeding species in both rural and urban settings across the island. The identified dominant species were Ae. polynesiensis and Ae. aegypti. No Ae. albopictus specimen was found. No field data are available for the last 5 years.

A survey conducted in 2004 in American Samoa [21] only reported Ae. aegypti and Ae. polynesiensis. Thus, it can be assumed that $A$ e. albopictus was absent from this country up to 2004. The situation is unknown regarding the 7 other countries, namely Kiribati, Nauru, Niue, Pitcairn, Western Samoa, Tokelau and Tuvalu for which, to the best of our knowledge, no studies, unpublished or otherwise or papers have considered the presence of $A e$. albopictus.

Regarding Vanuatu, no recent specific publications have been found, but according to WHO entomologist (Dr. Chang Moh Seng, personal communication, 2011), the species probably is currently present but this needs to be confirmed.

In Tonga, the species has been present, at least since 2011. Aedes albopictus specimens were collected in June 2011 as part of a training workshop held in Tonga's capital Nuku'alofa, Immature specimens were found coexisting with Ae. aegypti in tires on the waterfront close to the main harbour, and in several types of containers in the locality of Vaiola (Table 2). One adult was captured in a BG Sentinel ${ }^{\circledR}$ trap in Vaiola (Figure 2). Morphological identification was performed using keys and descriptions from Belkin [15]. The risk of misidentification with local Stegomyia species was dealt with using complementary documents [22,23]. Some collected individuals were compared to reference specimens from other areas for further confirmation (i.e. Europe, Reunion Island). Finally, molecular confirmation was established by PCR amplification and sequencing of approximately $460 \mathrm{bp}$ of the mitochondrial cytochrome oxidase I (COI) gene [24]. Sequences obtained for 4 specimens (3 females, 1 male) were $>99 \%$ identical to corresponding Ae. albopictus GenBank entries. This is the first report of this species in the Kingdom of Tonga.

A prior larval survey conducted in 2007 on the main island of Tongatapu and in the Vava'u group revealed the presence of 8 species including Ae. aegypti and the local member of the Scutellaris group, Aedes tongae [25]. No Ae. albopictus was found at the time. Aedes 
Table 2 Details of immature mosquito sampling in Tongatapu, 26-30 June 2011

\begin{tabular}{|c|c|c|c|c|}
\hline Locality & Sampling place & Container type & Aedes albopictus & Aedes aegypti \\
\hline Nuku'Alofa & Waterfront street & Tyre & 4 & - \\
\hline Nuku'Alofa & Hotel backyard - Waterfront & Tyre & 2 & - \\
\hline Nuku'Alofa & Waterfront street close to cemetery & Tyre & 37 & 14 \\
\hline Vaiola & Auto repair workshop & Large tyre & - & 1 \\
\hline Vaiola & Auto repair workshop & 4lt metallic can & 1 & 12 \\
\hline Vaiola & Auto repair workshop & Coconut shell & 2 & - \\
\hline Vaiola & Auto repair workshop & 4lt can with soil & 6 & - \\
\hline Vaiola & Auto repair workshop & Small tyre & - & 49 \\
\hline Vaiola & Auto repair workshop & Bucket & 29 & 1 \\
\hline \multirow[t]{2}{*}{ Vaiola } & Restaurant & Plant pot & 6 & 7 \\
\hline & Total & & 87 & 84 \\
\hline
\end{tabular}

albopictus and Ae. tongae can be sorted at larval stage owing to clear taxonomic differences such as the saddle, which is complete on the anal segment of Ae. tongae, but ventrally interrupted in Ae. albopictus $[15,26]$. This suggests a recent introduction and establishment of Ae. albopictus in Tonga.

\section{Conclusion}

Based on literature analyses and our own field investigations, the presence of Ae. albopictus is confirmed in 5 out of 17 countries and territories of the Southern Pacific Ocean (Table 1). The establishment in Tonga is not surprising due to its proximity to Fiji where $A e$.

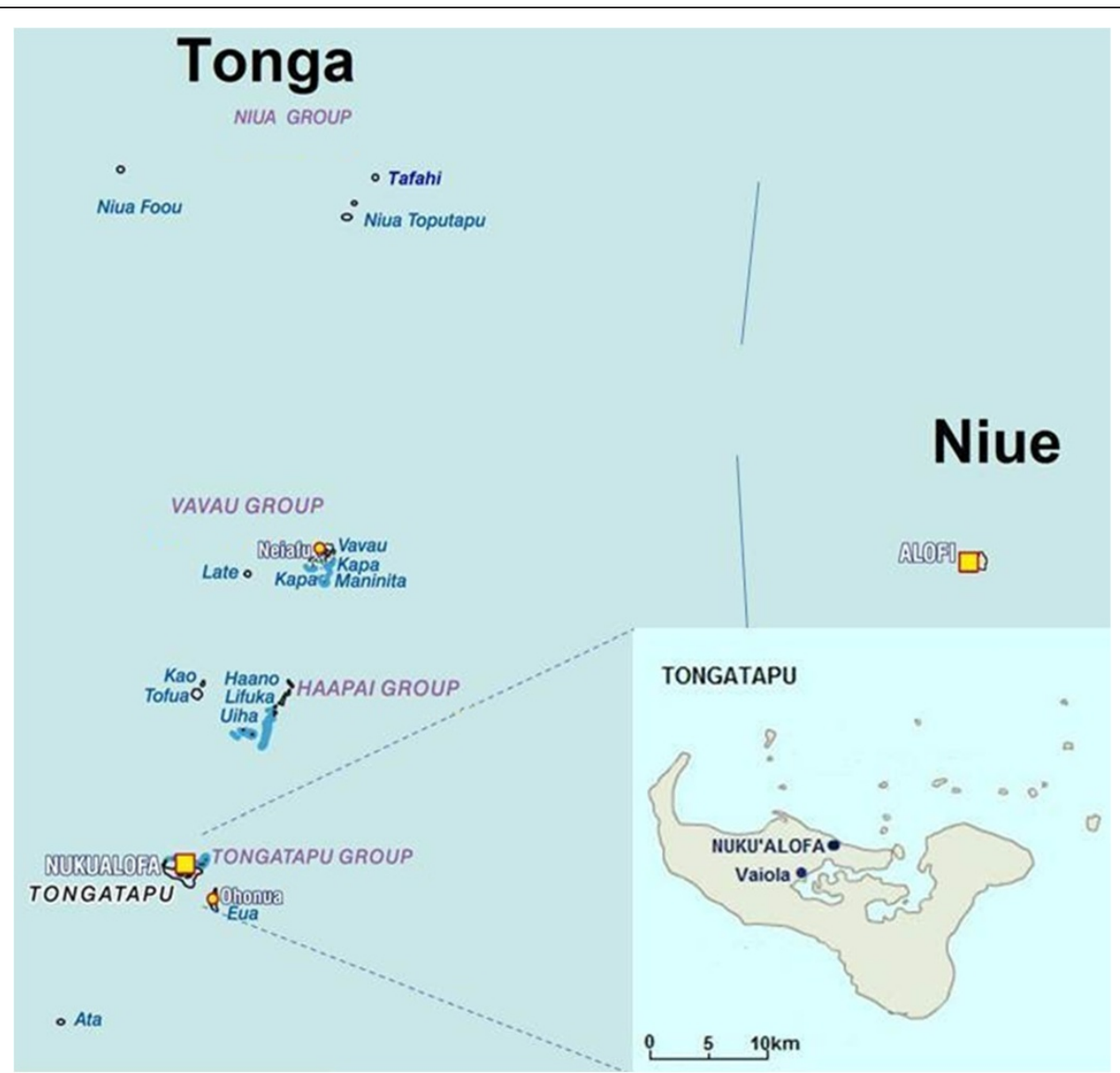

Figure 2 Map of Tonga showing the localities where Aedes albopictus was found. Modified from WHO with permission. 
albopictus has been present since 1989, and due to the intense sea and air traffic of passengers and goods between these two countries. Although the classical mode of introduction consists of the transfer of eggs through the tire trade, the invasive mosquito could also have been introduced as larvae or even adults transported in trade ships.

Combined with the emergence of mosquito-borne viruses such as chikungunya in the Pacific region [27], the establishment of Ae. albopictus in several PICTs where Ae. aegypti is already present likely increases the risk of arbovirus transmission since the former species colonizes a broader range of habitats, thus increasing the overall vector density. Consequently, regular vector surveillance to detect the introduction of Ae. albopictus into new areas should be conducted regularly in PICTs and, if occurring, appropriate vector control measures should be implemented immediately.

While the hypothesis formulated by Belkin to explain the absence of Ae. albopictus in the south Pacific region might have held true fifty years ago, the situation has dramatically changed with an increase in urbanisation and international trade at levels certainly not predictable at that time. In Fiji and now in Tonga, the presence of local Stegomyia species clearly did not prevent Ae. albopictus from establishing. Undoubtedly, the intensified trade at international and regional level means that many Pacific island countries most likely have encountered Ae. albopictus on multiple occasions. The reason why Ae. albopictus has not established in these islands is not clear. The factors driving the success or failure of the establishment of Ae. albopictus in Pacific island settings are not well understood. The study of Ae. albopictus on islands where it coexists with local Stegomyia species would shed some light on how these species cohabit. The discovery of Ae. albopictus in new PICTs is of great concern as it may be indicative of a slow but ineluctable trend of invasion through the Pacific region like in other areas of the world.

\section{Competing interests}

The authors declare having no competing interests.

\section{Authors' contributions}

LG carried out the entomological surveillance in New Caledonia, performed the investigations in Wallis and Futuna, Cook Islands and Tonga, and drafted the paper. RO contributed to the field work in Tonga. LS and NS contributed to the field work in Cook Islands and Tonga. HB carried out the entomological surveillance in French Polynesia and edited the manuscript. FS performed the morphological and molecular identification and edited the manuscript. All authors reviewed and approved the final manuscript.

\section{Acknowledgements}

The publication of these findings would not have been possible without the financial and/or organisational participation of: the Government of New Caledonia, the Government of French Polynesia, the Environment Agency of Wallis and Futuna, the Ministry of Health of Cook Islands, the Ministry of Health of Tonga, the Secretariat of the Pacific Community, and the French Development Agency. The authors also thank Dr Chang Moh Seng (WHO) for sharing information about Vanuatu, and Prof. A. Mathis for his useful comments and suggestions about the manuscript.

\section{Author details}

${ }^{1}$ Institut Pasteur de Nouvelle Calédonie, 9-11 Avenue Paul Doumer, Association Pasteur International Network ,Nouvelle-caledonie, Noumea BP 61, 98845, New Caledonia. ${ }^{2}$ Ministry of Health, Nuku'alofa, Kingdom of Tonga. ${ }^{3}$ Retired WHO Technical Officer, Tontouta, New Caledonia. ${ }^{4}$ Secretariat of the Pacific Community, Suva, Fiji. ${ }^{5}$ Institut Louis Malardé, Papeete, Tahiti, French Polynesia. Institute of Parasitology, University of Zurich, Zurich, Switzerland.

Received: 5 October 2012 Accepted: 31 October 2012

Published: 6 November 2012

\section{References}

1. Benedict MQ, Levine RS, Hawley WA, Lounibos LP: Spread of the tiger: global risk of invasion by the mosquito Aedes albopictus. Vector Borne Zoonotic Dis 2007, 7:76-85.

2. Kuno G: Research on dengue and dengue-like illness in East Asia and the Western Pacific during the First Half of the 20th century. Rev Med Virol 2007, 17:327-341.

3. Effler PV, Pang L, Kitsutani P, Vorndam V, Nakata M, Ayers T, Elm J, Tom T, Reiter P, Rigau-Perez JG, et al: Dengue fever, Hawaii, 2001-2002. Emerg Infect Dis 2005, 11:742-749.

4. Michault A: Insularite et risques epidemiques a La Reunion. Bull Soc Pathol Exot 1998, 91:52-55.

5. Pierre V, Thiria J, Rachou E, Lassalle C, Sissoko D, Renault P: Dengue fever outbreak in La Réunion Island in 2004. In Poster International congress "Medicine and health in the tropics". Edited by Pierre V, Thiria J, Rachou E, Lassalle C, Sissoko D, Renault P. Marseille: International Water Association Publishing; 2006.

6. Reiter P, Fontenille D, Paupy C: Aedes albopictus as an epidemic vector of chikungunya virus: another emerging problem? Lancet Infect Dis 2006, 6:463-464.

7. Angelini $P$, Macini $P$, Finarelli AC, Pol C, Venturelli C, Bellini R, Dottori M: Chikungunya epidemic outbreak in Emilia-Romagna (Italy) during summer 2007. Parassitologia 2008, 50:97-98.

8. Grandadam M, Caro V, Plumet S, Thiberge JM, Souares Y, Failloux AB, Tolou HJ, Budelot M, Cosserat D, Leparc-Goffart I, Despres P: Chikungunya virus, southeastern France. Emerg Infect Dis 2011, 17:910-913.

9. Paupy C, Ollomo B, Kamgang B, Moutailler S, Rousset D, Demanou M, Herve JP, Leroy E, Simard F: Comparative role of Aedes albopictus and Aedes aegypti in the emergence of Dengue and Chikungunya in central Africa. Vector Borne Zoonotic Dis 2010, 10:259-266.

10. Medlock JM, Hansford KM, Schaffner F, Versteirt V, Hendrickx G, Zeller H, Bortel W: A review of the invasive mosquitoes in europe: ecology, public health risks, and control options. Vector Borne Zoonotic Dis 2012, 12:435-447.

11. Paupy C, Delatte H, Bagny L, Corbel V, Fontenille D: Aedes albopictus, an arbovirus vector: from the darkness to the light. Microbes Infect 2009, 11:1177-1185.

12. Cancrini G, Frangipane Di Regalbono A, Ricci I, Tessarin C, Gabrielli S, Pietrobelli M: Aedes albopictus is a natural vector of Dirofilaria immitis in Italy. Vet Parasitol 2003, 118:195-202.

13. Rosen L, Rozeboom LE, Reeves WC, Saugrain J, Gubler DJ: A field trial of competitive displacement of Aedes polynesiensis by Aedes albopictus on a Pacific atoll. AmJTrop Med Hyg 1976, 25:906-913.

14. Duffy MR, Chen TH, Hancock WT, Powers AM, Kool JL, Lanciotti RS, Pretrick M, Marfel M, Holzbauer S, Dubray C, et al: Zika virus outbreak on Yap Island, Federated States of Micronesia. N Engl J Med 2009, 360:2536-2543.

15. Belkin JN: The mosquitoes of the South Pacific. Berkeley and Los Angeles: Univ. Calif. Press; 1962.

16. Cooper RD, Waterson DGE, Kupo M, Sweeney AW: Aedes albopictus (Skuse) (Diptera: Culicidae) in the Western Province of Papua New Guinea and the Threat of its Introduction to Australia. J Austent Soc 1994, 33:115-116.

17. Elliott SA: Aedes albopictus in the Solomon and Santa Cruz Islands, South Pacific. Trans R Soc Trop Med Hyg 1980, 74:747-748.

18. Laille M, Fauran P, Rodhain F: The presence of Aedes (Stegomyia) albopictus in the Fiji Islands. Bull Soc Pathol Exot 1990, 83:394-398.

19. Knudsen AB: Global distribution and continuing spread of Aedes albopictus. Parassitologia 1995, 37:91-97. 
20. Ritchie SA, Long S, Hart A, Webb CE, Russell RC: An adulticidal sticky ovitrap for sampling container-breeding mosquitoes. J Am Mosq Control Assoc 2003, 19:235-242.

21. Lambdin BH, Schmaedick MA, McClintock S, Roberts J, Gurr NE, Marcos K, Waller L, Burkot TR: Dry season production of filariasis and dengue vectors in American Samoa and comparison with wet season production. AmJTrop Med Hyg 2009, 81:1013-1019.

22. Huang YM, Hitchcock JC: A revision of the Aedes Scutellaris group of Tonga (Diptera, Culicidae). Contributions of the American Entomological Institute 1980, 17:1-107.

23. Ramalingam S: An Annotated Checklist and Keys to the Mosquitoes of Samoa and Tonga. Mosquito Systematcs 1976, 8:298-318.

24. Wenk CE, Kaufmann C, Schaffner F, Mathis A: Molecular characterization of Swiss Ceratopogonidae (Diptera) and evaluation of real-time PCR assays for the identification of Culicoides biting midges. Vet Parasitol 2012. 184:258-266.

25. Harding JS, Brown C, Jones F, Taylor R: Distribution and habitats of mosquito larvae in the Kingdom of Tonga. Australian Journal of Entomology 2007, 46:332-338.

26. Rueda LM: Pictorial keys for the identification of mosquitoes (Diptera: Culicidae) associated with Dengue Virus Transmission. Zootaxa 2004, 589:33-41.

27. Alibert A, Pfannstiel A, Grangeon JP: Chikungunya outbreak in New Caledonia in 2011, Status report as at 22 August 2011. Inform'Action 2011, 34:3-9.

doi:10.1186/1756-3305-5-247

Cite this article as: Guillaumot et al:: Distribution of Aedes albopictus (Diptera, Culicidae) in southwestern Pacific countries, with a first report from the Kingdom of Tonga. Parasites \& Vectors 2012 5:247.

\section{Submit your next manuscript to BioMed Central and take full advantage of:}

- Convenient online submission

- Thorough peer review

- No space constraints or color figure charges

- Immediate publication on acceptance

- Inclusion in PubMed, CAS, Scopus and Google Scholar

- Research which is freely available for redistribution 